\title{
34. DETERMINATION OF RARE-EARTH ELEMENTS IN LEG 51, SITE 417 SAMPLES
}

\author{
Hiroshi Shimizu, Akimasa Masuda, and Tadahide Ui, Department of Earth Sciences, Kobe University, Nada, Kobe, Japan
}

\begin{abstract}
Six samples from Holes 417A and 417D, near the southern end of the Bermuda Rise, and one sample (AII-92-29-1) from $23^{\circ} \mathrm{N}$ Mid-Atlantic Ridge were analyzed for a highly precise determination of REE, Ba, and $\mathrm{Sr}$. As anticipated from theoretical considerations, employment of ordinary linear scale for vertical axis proved strikingly expedient in realizing the comparatively fine but significant characeristics of chondrite-normalized REE patterns of abyssal tholeiites or the like; the Leedey chondrite is employed for normalization.

The abundances of $\mathrm{Nd}$ are high for rocks with steeper inclinations for heavy REE (HREE) span. When a regression line is drawn, La and Nd deviate in a negative direction and $\mathrm{Ce}$ in a positive direction; there is a correlation between the extents of $\mathrm{La}$ deviation and $\mathrm{Ce}$ deviation. Moreover, the sum of squares of deviations, $\Delta \mathrm{La}, \Delta \mathrm{Ce}$, and $\Delta \mathrm{Nd}$, from the regression line for the La-Ce-Nd span increases with the increase of HREE inclination. These observations can be theoretically understood through quantitative study. Meanwhile, it is concluded that the Bermuda Rise rocks correspond to solid-type material system involved with separation from a melt with almost horizontal REE patterns, indicating the $F_{w}^{a}$ value is close to unity. In a relative sense, AII-92-29-1 reflects the separation from melt with a smaller $\mathrm{fw}$. Also, it is worth pointing out that the extensions of regression lines for the Hole 417A and 417D samples intersect the abscissa around $-3.3 \sim-3.4$.
\end{abstract}

\section{INTRODUCTION}

Recently, REE data on abyssal tholeiites have been reported by an increasing number of investigators. An overwhelming majority of abyssal tholeiites show light REE-depleted patterns (Frey and Haskin, 1964; Kay et al., 1970; Schilling, 1971; Kay and Hubbard, 1978), but LREE-enriched patterns have been found (Langmuir et al., 1977; Schilling, 1976; Dostal and Muecke, 1977; Puchelt and Emmermann, 1977; Puchelt et al., 1977), as well as V-shaped ones (Schilling, et al., 1977).

The LREE-depleted REE patterns correspond to those which were designated by Masuda (1966) as solid-type patterns. It is regrettable that those LREE-depleted REE patterns usually are considered as almost identical, and little distinction has been made among them. This is due in part to insufficient accuracies in REE determination. Additionally, this might be attributed to the procedure conventionally employed.

In this introduction, a somewhat detailed explanation will be given to mathematical background developed by one of us (A.M.) for REE pattern analyses and related problems. Masuda (1962) and Coryell et al. (1963) presented a valuable plotting method, in which the logarithms of chondritenormalized values are plotted against the differences in atomic numbers of REE. They emphasized the linearity of patterns resulting from such a plotting procedure. According to mathematical analyses by Masuda and Matsui (1966), such a striking linearity is characteristic of liquid-type materials (Masuda, 1966). The MC plot (named for Masuda-
Coryell plot) is of essential significance for liquid-type materials. However, it should be kept in mind that, mathematically, the MC plot for solid-type materials is for convenience in distinguishing diagrammatically between liquidtype and solid-type materials, and is less significant than for liquid-type materials.

When the bulk partition coefficient is $\mathrm{k}$, and the residual melt fraction is assumed to be $\mathrm{f}_{\mathrm{w}}$, the ratio of the concentration $\mathrm{C}_{\mathrm{I}}$ in the residual melt relative to the initial concentration $\mathrm{C}_{\mathrm{o}}$ is given by

$$
\log C_{1} / C_{o}=-(1-k) \log f_{w}
$$

The corresponding concentration $\mathrm{C}_{\mathrm{s}}$ in the solid surface in equilibrium with the coexisting melt phase should satisfy the relation

$$
\mathrm{C}_{\mathrm{s}}=\mathrm{kC}_{1}
$$

In the above mathematical treatment, equilibrium between the solid surface or forming solid and melt is assumed to hold. Of course, it should be noted that naturally occurring solid-type materials represent systems resulting from accumulation of "solids" in sequential solid-surface equilibrium with diminishing melt phase. A solid-type material can be dealt with as a system which accumulated between two solidification stages corresponding to residual melt fractions, $f_{w}^{a}$ and $f_{w}^{b}$ (see Appendix), where $f_{w}^{a}$ is arbitrarily taken greater than $\mathrm{fw}_{\mathrm{w}}^{\mathrm{b}}$. As proved by Masuda and 
Matsui (1966), the logarithmic linearity of REE pattern of liquid-type material for a span of REE in a MC plot is a reflection of simple linearity of bulk partition coefficients themselves which are responsible for the observed fractionation. This mathematical consideration leads us to a conclusion that, when $\mathrm{f}_{\mathrm{w}}^{\mathrm{a}}$ is near unity or a considerably large value, employment of an ordinary linear scale (not a logarithmic scale) as a vertical axis can be essentially significant. (For this reason, Masuda et al. [1977] employed the ordinary linear scale for the vertical axis in their discussions of REE geochemistry of basalt from Ulwan volcano, New Britain.)

We have analyzed six samples from Holes $417 \mathrm{~A}$ and 417D and one sample (AII-92-29-1) from the Mid-Atlantic Ridge $\left(23^{\circ} 02.63^{\prime} \mathrm{N} / 45^{\circ} 01.05^{\prime} \mathrm{W}\right)$, for rare-earth elements (REE). This paper is based on the mathematical considerations mentioned above. An ordinary linear scale has been used for the ordinate, which enabled us to distinguish among REE patterns of abyssal tholeiites. It will be shown that highly precise determination of REE and the interpretative viewpoint originating from Masuda (1963) are very valuable and promising.

Bermuda Rise rocks investigated were obtained by drilling near the southern end of the Bermuda Rise; their age is estimated to be older than $100 \times 10^{6} \mathrm{yr}$ (Donnelly, Francheteau et al., 1977).

\section{RESULTS}

Samples investigated are described in Table 1. Rare-earth elements were determined by mass spectrometric stable isotope dilution technique, with accuracies of better than 1 per cent. However, Gd for Section 417A-41-5 may involve an uncertainty of nearly 2 per cent. The results of determinations of REE, $\mathrm{Ba}$, and $\mathrm{Sr}$ are presented in Table 2. For our data presented here, uncertainties in isotope dilution analyses of $\mathrm{Ba}$ and $\mathrm{Sr}$ are 2 to 3 per cent and 3 to 4 per cent, respectively; these elements were not determined with the same cautions as exercised in REE determination. Major chemical compositions of rocks studied in this report are tabulated in Table 3 (Ui et al., this volume).

\section{DISCUSSION}

\section{Comparison of General Patterns Plotted Against a Logarithmic Scale}

Figure 1 presents the MC plots where the vertical axis refers to logarithmic scale. In a gross sense, the REE patterns appear to be similar to each other. That is, when the logarithmic ordinate is used for solid-type material, it is often difficult for us to recognize comparatively fine but clearly significant distinctions among solid-type REE patterns. The advantages of ordinary scale over logarithmic scale depend on the values concerned of $f_{w}$, the procedure of mathematical treatment, and (to a lesser extent) the natures of subjects.

High concentrations of $\mathrm{Ba}$ are noted in an altered rock (Section 417A-24-1). For unaltered rocks, the chondritenormalized values are around unity, while the corresponding value for Section 417A-24-1 is about 50, clearly indicating the enhancement of $\mathrm{Ba}$ content due to alteration. How-
TABLE 1

Descriptions of Samples Analyzed

417A-24-1 Pillow basalt : plag.-phyric

417A-41-5 Pillow basalt : plag., ol., cpx.-phyric

417A-44-3 Dolerite

417D-22-4 Pillow basalt : plag., ol.-phyric

417D-32-6 Massive basalt

417D-45-1 Pillow basalt : plag., ol., cpx.-phyric

AII-92-29-1 Dredged sample from $23^{\circ} 02.63^{\prime} \mathrm{N} / 45^{\circ} 01.05^{\prime} \mathrm{W}$

TABLE 2

Abundances (ppm) of REE, Ba, and $\mathrm{Sr}$ in Rocks Investigated

\begin{tabular}{lccccccc}
\hline & $417 \mathrm{~A}-24-1$ & $417 \mathrm{~A}-41-5$ & $417 \mathrm{~A}-44-3$ & $417 \mathrm{D}-22-4$ & $417 \mathrm{D}-32-6$ & $417 \mathrm{D}-45-1$ & All-92-29-1 \\
\hline $\mathrm{La}$ & 2.68 & 2.08 & 2.40 & 2.20 & 2.22 & 2.41 & 4.12 \\
$\mathrm{Ce}$ & 9.44 & 7.01 & 8.13 & 7.52 & 7.44 & 8.56 & 13.36 \\
$\mathrm{Nd}$ & 9.79 & 7.42 & 8.65 & 8.01 & 7.88 & 9.15 & 12.59 \\
$\mathrm{Sm}$ & 3.58 & 2.75 & 3.21 & 2.92 & 2.95 & 3.42 & 4.30 \\
$\mathrm{Eu}$ & 1.259 & 1.028 & 1.201 & 1.124 & 1.127 & 1.279 & 1.550 \\
$\mathrm{Gd}$ & 5.01 & 3.95 & 4.71 & 4.29 & 4.31 & 5.01 & 5.93 \\
$\mathrm{Dy}$ & 6.01 & 4.94 & 5.81 & 5.38 & 5.39 & 5.96 & 6.94 \\
$\mathrm{Er}$ & 3.44 & 3.11 & 3.65 & 3.35 & 3.38 & 3.60 & 4.25 \\
$\mathrm{Yb}$ & 3.04 & 3.04 & 3.55 & 3.32 & 3.28 & 3.32 & 4.03 \\
$\mathrm{Lu}$ & 0.439 & 0.457 & 0.541 & 0.504 & 0.511 & 0.488 & 0.606 \\
$\mathrm{Ba}$ & 225 & 4.96 & - & - & - & 4.22 & 5.55 \\
$\mathrm{Sr}$ & 107 & 155 & - & - & - & 124 & 138 \\
\hline
\end{tabular}

TABLE 3

Major Chemical Compositions (after Ui et al., this volume)

\begin{tabular}{lcrrrrrr}
\hline & $417 \mathrm{~A}-24-1$ & $417 \mathrm{~A}-41-5$ & $417 \mathrm{~A}-44-3$ & $417 \mathrm{D}-22-4$ & $417 \mathrm{D}-32-6$ & $417 \mathrm{D}-45-1$ & All-92-29-1 \\
\hline $\mathrm{SiO}_{2}$ & 48.14 & 48.06 & 48.59 & 46.83 & 47.99 & 46.69 & 48.79 \\
$\mathrm{TiO}_{2}$ & 1.47 & 1.35 & 1.52 & 1.38 & 1.46 & 1.68 & 1.81 \\
$\mathrm{Al}_{2} \mathrm{O}_{3}$ & 17.67 & 16.47 & 16.32 & 16.64 & 15.87 & 16.09 & 16.15 \\
$\mathrm{Fe}_{2} \mathrm{O}_{3}$ & 7.48 & 4.54 & 4.07 & 4.25 & 3.82 & 4.93 & 2.13 \\
$\mathrm{FeO}$ & 0.49 & 5.71 & 6.13 & 5.17 & 5.91 & 4.88 & 7.82 \\
$\mathrm{MnO}$ & 0.13 & 0.16 & 0.17 & 0.18 & 0.15 & 0.17 & 0.17 \\
$\mathrm{MgO}$ & 2.61 & 6.16 & 7.06 & 6.89 & 6.41 & 7.10 & 7.61 \\
$\mathrm{CaO}$ & 3.00 & 12.93 & 12.28 & 12.52 & 12.73 & 10.72 & 11.19 \\
$\mathrm{Na}_{2} \mathrm{O}$ & 1.43 & 2.13 & 2.21 & 2.36 & 2.26 & 2.51 & 2.83 \\
$\mathrm{~K}_{2} \mathrm{O}$ & 6.72 & 0.07 & 0.08 & 0.08 & 0.09 & 0.10 & 0.17 \\
$\mathrm{H}_{2} \mathrm{O}+$ & 5.79 & 1.66 & 0.80 & 1.92 & 2.04 & 1.93 & 0.78 \\
$\mathrm{H}_{2} \mathrm{O}-$ & 4.71 & 0.72 & 0.62 & 1.67 & 0.95 & 2.82 & 0.34 \\
$\mathrm{P}_{2} \mathrm{O}_{5}$ & 0.20 & 0.18 & 0.14 & 0.20 & 0.13 & 0.04 & 0.26 \\
$\mathrm{Total}^{-9}$ & 99.84 & 100.14 & 99.99 & 100.09 & 99.81 & 99.66 & 100.05 \\
\hline
\end{tabular}

Note: Analysis by H. Haramura.

ever, the REE pattern cannot be judged as affected by alteration. It is true that there is some difference between Section 417A-24-1 and the other two samples from Hole 417A, but this difference can be understood as unrelated with the alteration process. Meanwhile, as seen in Table 2, the $\mathrm{Sr}$ content appears totally unaffected by the alteration.

Frey et al. (1974) suggested that the alteration process is accompanied by enrichment of $\mathrm{Ba}, \mathrm{Sr}$, and LREE, but their suggestions cannot always be regarded as conclusive, because liquid-type materials seem to be involved therein. Other researchers mention that the alteration process does not change $\mathrm{Sr}$ and REE contents (Philpotts et al., 1969; Hart, 1976). Enrichment of Ba by a factor of about 50 without any increase of $\mathrm{Sr}$ content as found by us would be the first finding; Hart (1976) reported the double enhancement of Ba content in an altered portion, and Philpotts et al. (1969) observed 50 per cent change of Ba due to alteration.

\section{Comparison of General Patterns Plotted Against an Ordinary Scale}

In preparing Figures 2 and 3, ordinary linear scale is employed for vertical axis. Unlike Figure 1, it is easy for us 


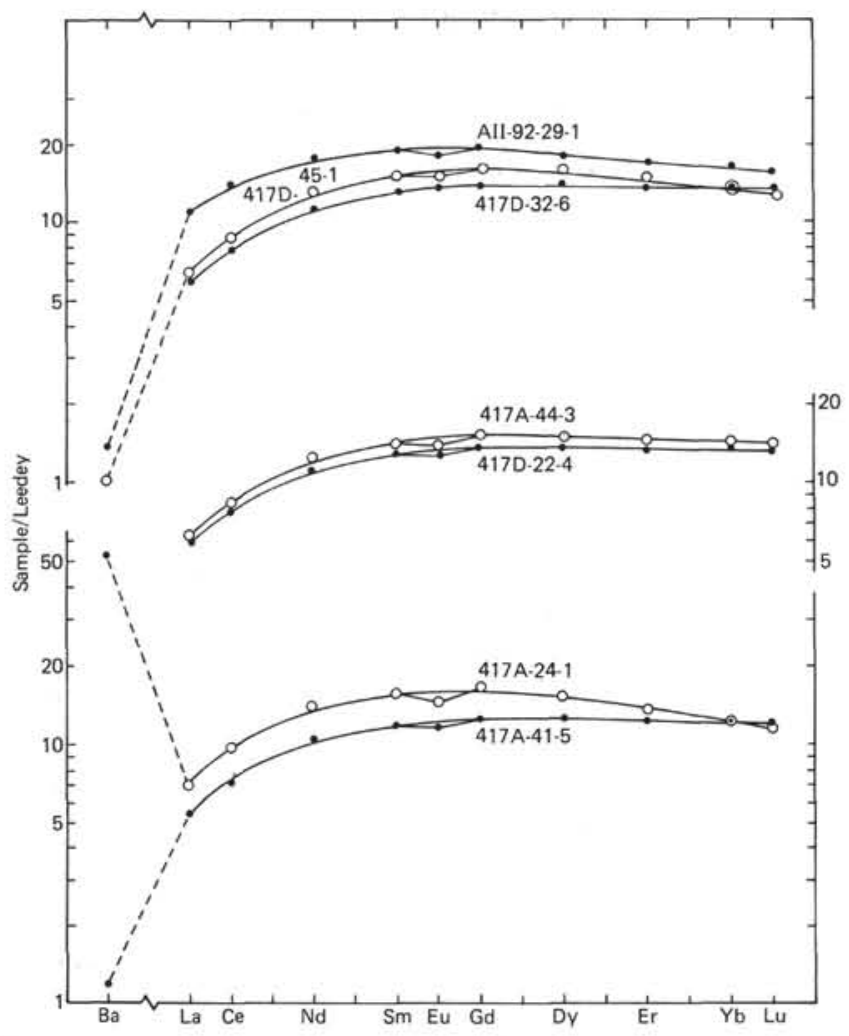

Figure 1. Chondrite-normalized REE patterns, using a logarithmic scale for the vertical axis.

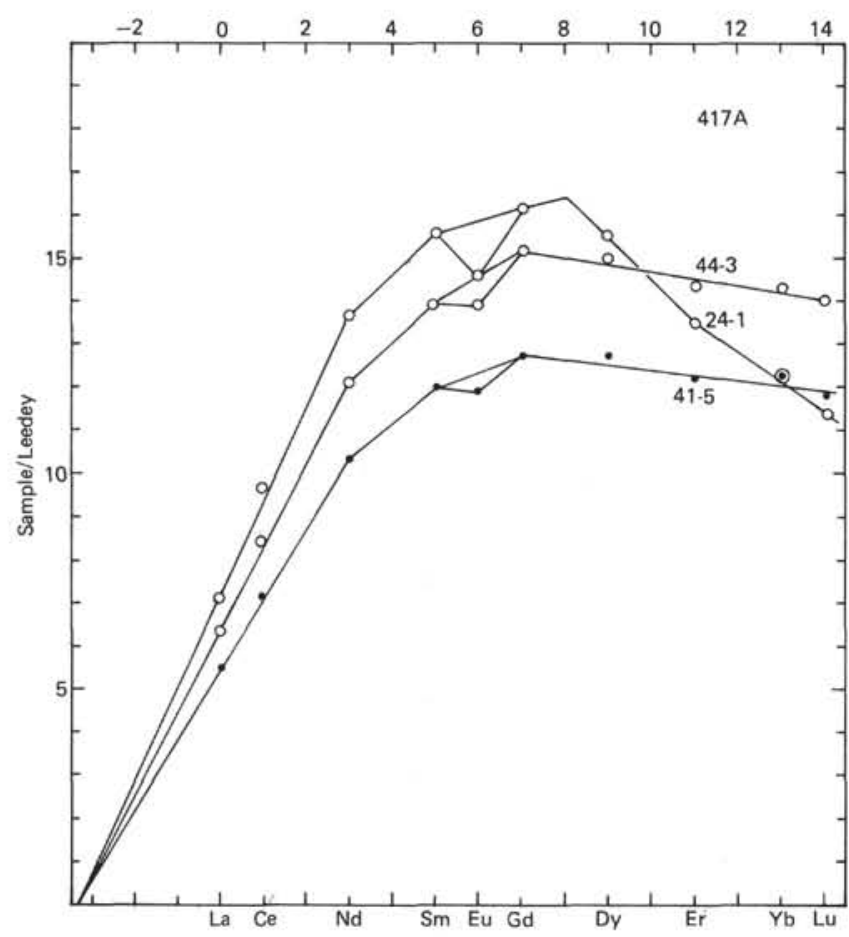

Figure 2. Chondrite-normalized REE patterns of Hole $417 \mathrm{~A}$ samples, using an ordinary linear scale for vertical axis, with exhibition of position of intersection with horizontal axis.

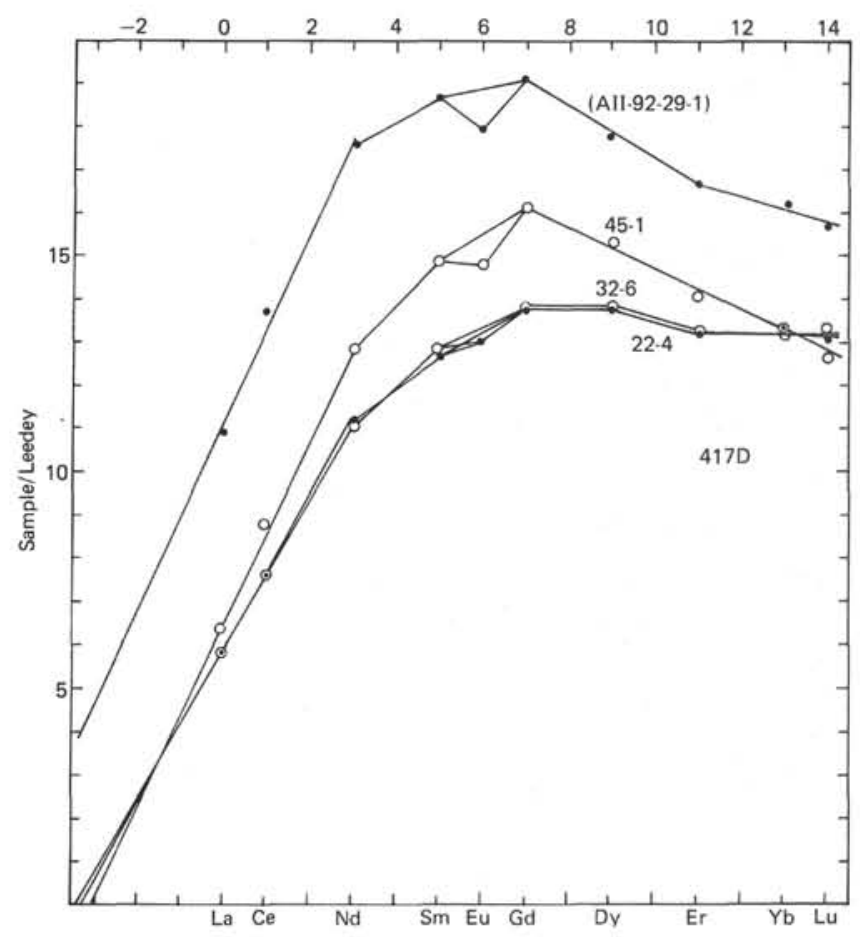

Figure 3. Chondrite-normalized REE patterns of Hole 417D samples and AII 92-29-1, using an ordinary linear scale for vertical axis, with exhibition of intersections of lines for $417 D$ samples with horizontal axis.

to detect specific features of REE patterns and recognize their differences. Generally, $\mathrm{La}, \mathrm{Ce}$, and $\mathrm{Nd}$ appear to plot along a straight line, even though there are small deviations from a strictly linear line. In half of the cases studied, Gd, $\mathrm{Dy}, \mathrm{Er}, \mathrm{Yb}$, and $\mathrm{Lu}$ appear to fall along another straight line. Thus, there appears a sharp break at Gd, while $\mathrm{Nd}$, $\mathrm{Sm}$, and Gd form a curved segment. Of the three samples from Hole 417A, the patterns for Sections 44-3 and 41-5 resemble each other quite well, and the abundance ratios between them reveal small aberrations ranging from +1.5 to -1.8 per cent relative to a mean value, with six of ten elements of REE determined falling within deviations of \pm 0.5 per cent. It is also worth pointing out that three lines drawn by the least-square method for $\mathrm{La}, \mathrm{Ce}$, and $\mathrm{Nd}$ of Hole 417A samples intersect the zero level at substantially the same position on the horizontal axis.

The REE patterns for three Hole 417D samples and AII-92-29-1 are shown in Figure 3 in a similar way as shown in Figure 2. Agreement between Sections 32-6 (massive basalt) and 22-4 (pillow basalt) is remarkably good. Also it is worth mentioning that Sections 32-6 and 22-4 are located above a possible fault zone, while Section 45-1 is from a position below this zone. It is evident that the abyssal tholeiite, AII-92-29-1, is markedly different from the Bermuda Rise rocks.

The positions of intersections of zero level by the extensions of lines drawn by least-square method for $\mathrm{La}, \mathrm{Ce}$, and $\mathrm{Nd}$ are as follows:

$\begin{array}{rrrr}417 \mathrm{~A}-24-1 & -3.36 & 417 \mathrm{D}-22-4 & -3.29 \\ 417 \mathrm{~A}-41-5 & -3.41 & 417 \mathrm{D}-32-6 & -3.44 \\ 417 \mathrm{~A}-44-3 & -3.36 & 417 \mathrm{D}-45-1 & -3.00 \\ & & \text { AII-92-29-1 } & -5.10\end{array}$


The numerical agreement in intersecting point among Hole 417A samples is in keeping with the observation in Figure 2 ; the negative values indicate the left-hand position relative to La which is taken, for convenience, as an original point of the horizontal axis. To a lesser extent, convergence of intersection among Hole 417D samples is good.

Attention should be called to the fact that the above values of intersections for Site 417 samples are very close to the corresponding value $(-3.3)$ for a bulk partition coefficient function estimated by Masuda and Matsui (1966) and for an experimentally obtained function (Experiment A of Masuda and Kushiro, 1970). A large absolute value for intersection for AII-92-29-1 would be explained reasonably (Masuda and Shimizu, 1978).

\section{Enlarged Diagrams With Deviations From Partial Regression Lines}

Figures $4 a, 4 b$, and $4 c$ are enlarged diagrams for individual samples from Hole $417 \mathrm{~A}$. Illustrations at the top exhibit the deviations of each of the REE points from straight lines obtained by application of least-square method

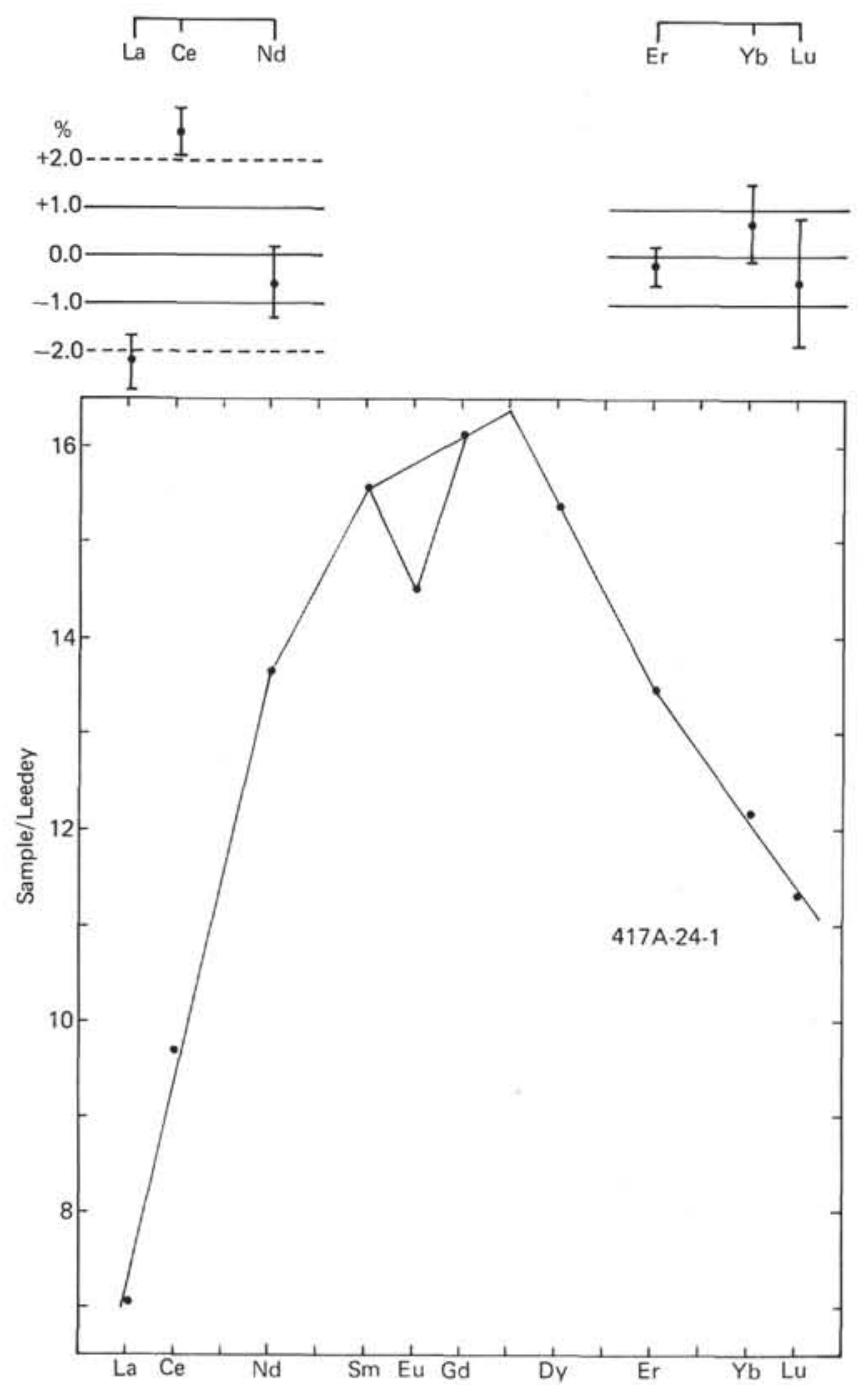

Figure 4a. Enlarged diagram for Section 417A-24-1 (cf. Figure 2), with deviations (\%) from regression lines.

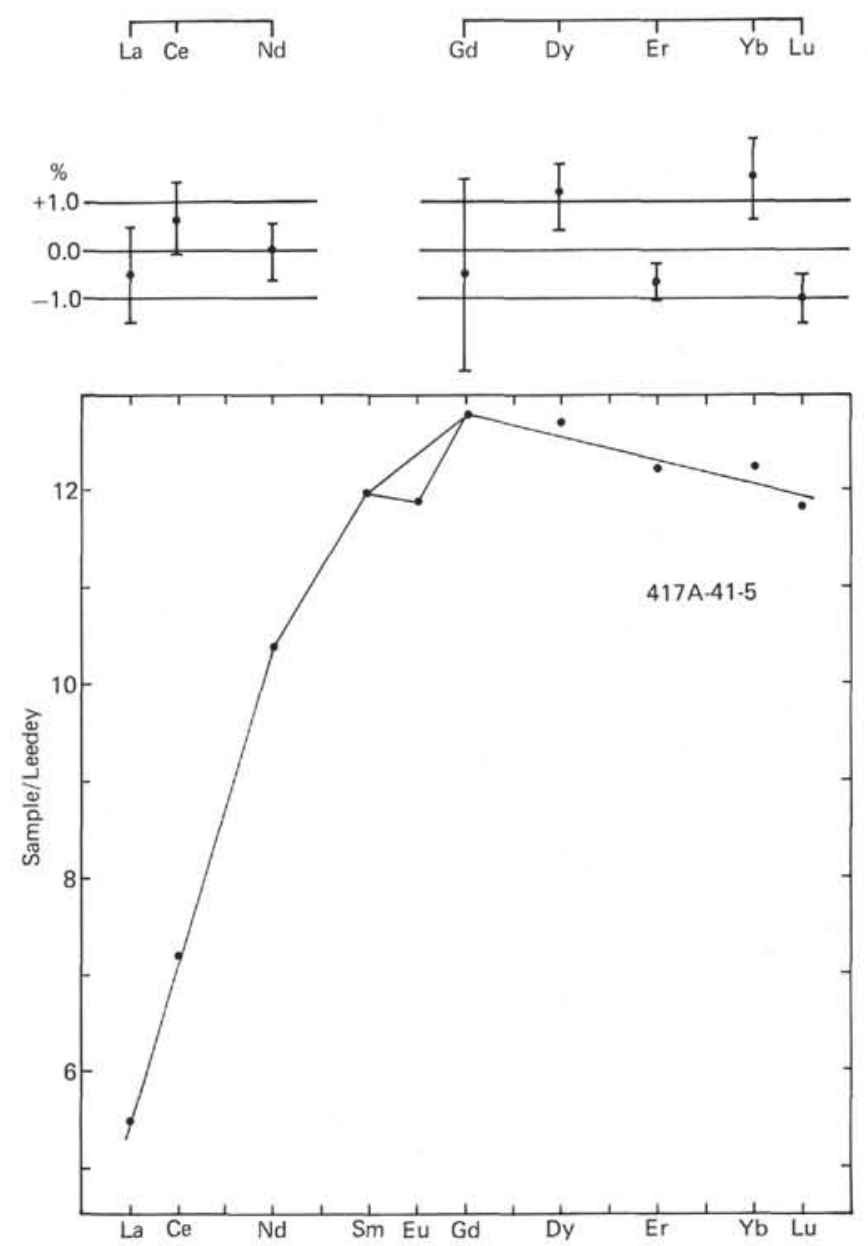

Figure 4b. Enlarged diagram for Section 417A-41-5 (cf. Figure 2), with deviations (\%) from regression lines.

to more than two points; the absence of a dot for Sm at the top is the result of the least-square method not being applied to a span covering $\mathrm{Sm}$. It will be seen that the deviations for Section 417 A-44-3 are within 1.1 per cent, but those for Section 417A-24-1 are much larger (in particular, the La-Ce-Nd span). Figures 5a, 5b, and 5c for Hole 417D samples and Figure 6 for AII are diagrams similar to Figure 4; HREE span for AII-92-29-1 is divided into two segments, Gd-Dy-Er and Er-Yb-Lu. Note that the deviation patterns for La, Ce, and Nd of Section 417D-45-1 and AII-92-29-1 resemble the corresponding one of Sample 417A-24-1.

\section{CONCLUSIONS}

It is seen (Figure 7) that the abundances of Nd generally are high for rocks with steeper inclinations for a heavy REE (HREE) span. Specifically, deviations of $\mathrm{La}, \mathrm{Ce}$, and $\mathrm{Nd}$ from the regression line are of essential significance. It should be noted that $\mathrm{Ce}$ deviates in a positive direction, while $\mathrm{La}$ and $\mathrm{Nd}$ deviate in a negative direction, and that there is a correlation between extents of deviations of La and $\mathrm{Ce}$. This means a convex curvature covering $\mathrm{La}, \mathrm{Ce}$, and $\mathrm{Nd}$, and the larger deviation indicates greater curvature. It should be emphatically noted, however, that the curvature under considertion does not contradict the strict linearity of bulk partition coefficients concerned, but mathematically is 
deduced strictly by assuming the bulk partition coefficients with strict linearity. As seen in Figure 8, the sum of squares of deviations, $\Delta \mathrm{La}, \Delta \mathrm{Ce}$, and $\Delta \mathrm{Nd}$, from the regression line increases with the increase of HREE inclination, IHRE.

All of these facts are theoretically quite reasonable and can be explained quantitatively. Two curves drawn in Figure 8 are based purely on theoretical calcuations; the two curves correspond to different parameters used in the calculation. Also, Figure 9 demonstrates that a theoretical reinstatement of IHREE to horizontality brings about a kind of covergence of $\mathrm{Ism}_{\mathrm{Gd}} / \mathrm{INd}_{\mathrm{N}-\mathrm{Sm}}$, where $\mathrm{Ism}_{\mathrm{smd}} \mathrm{Gd}$ and $\mathrm{INd-Sm}$ refer to inclinations joining $\mathrm{Sm}$ and $\mathrm{Gd}$ and $\mathrm{Nd}$ and $\mathrm{Sm}$, respectively. For the igneous rocks studied here, the relevant bulk partition coefficients of $\mathrm{Nd}, \mathrm{Sm}$, and Gd are regarded nonlinear for this span and such a case is actually observed in Experiment A carried out by Masuda and Kushiro (1970). A detailed explanation of procedures of theoretical calculations will be presented elsewhere (Masuda and Shimizu, 1978).

We conclude that the Bermuda Rise rocks investigated represent the solid-type material systems entangled with high $\mathrm{f}_{w}^{\mathrm{a}}$ values close to unity, whereas the $\mathrm{f}_{w}^{\mathrm{a}}$ value responsible for the genesis of the rock in AII-92-29-1 is estimated to be comparatively small. The high $\mathrm{f}_{\mathrm{w}}^{\mathrm{a}}$ values mean the effect of separation from melts with horizontal or almost horizontal REE patterns.

\section{REFERENCES}

Coryell, C.D., Chase, J.W., and Winchester, J.W., 1963. A procedure for geochemical interpretation of terrestrial rareearth abundance patterns, J. Geophys. Res., v. 68, p. 559-566.

Donnelly, T.W., Francheteau, J., et al., 1977. Mid ocean ridge in the Cretaceous, Geotimes, v. 22, p. 20-23.

Dostal, J. and Muecke, G.K., 1977. Trace element geochemistry of igneous rocks from Site 334, Leg 37, In Aumento, F., Melson, W.G., et al., Initial Reports of the Deep Sea Drilling Project, v. 37: Washington (U.S. Government Printing Office), p. 573-576.

Frey, F.A., Bryan, W.B., and Thompson, G., 1974. Atlantic ocean floor: Geochemistry and petrology of basalts from Legs 2 and 3 off the Deep-Sea Drilling Project, J. Geophys. Res., v. 79. p. $5507-5527$.

Frey, F.A. and Haskin, L., 1964. Rare earths in oceanic basalts, $J$. Geophys. Res., v. 69, p. 775-779.

Hart, S.R., 1976. LIL-element geochemistry, Leg 34 basalts. In Hart, S.R., Yeats, R.S., et al., Initial Reports of Deep Sea Drilling Project, v. 34: Washington (U.S. Government Printing Office), p. 283-288.

Kay, R.W. and Hubbard, N.J., 1978. Trace elements in ocean ridge basalts, Earth Planet. Sci. Lett., v. 38, p. 95-116.

Kay, R.W., Hubbard, N.J., and Gast, P.W., 1970. Chemical characteristics and origin of ocean ridge volcanic rocks, $J$. Geophys. Res., v. 75, p. 1585-1614.

Langmuir, C.H., Bender, J.F., Bence, A.E., and Hanson, G.N., 1977. Petrogenesis of basalts from the FAMOUS area: MidAtlantic Ridge, Earth Planet. Sci. Lett., v. 36, p. 133-156.

Masuda, A., 1962. Regularities in variation of relative abundances of lanthanide elements and an attempt to analyse separationindex patterns of some minerals, J. Earth Sci., Nagoya Univ., v. 10, p. $173-187$.

1963. On the diversity of abundance patterns for lanthanide elements in rocks, INSJ-52, Inst. Nucl. Study, Univ. of Tokyo.

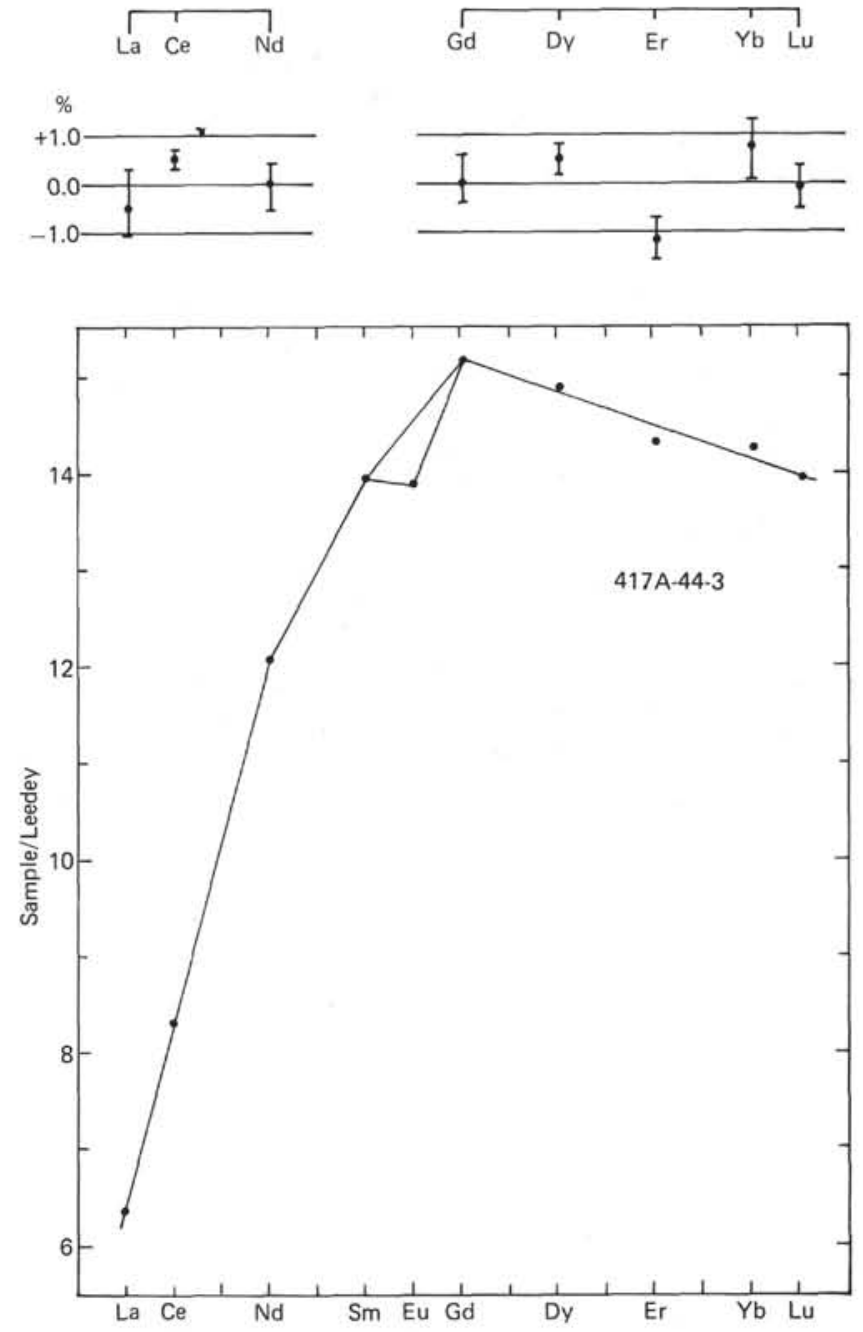

Figure 4c. Enlarged diagram for Section 417A-44-3 (cf. Figure 2), with deviations (\%) from regression lines.

1966. Lanthanides in basalts of Japan with three distinct types, Geochem. J., v. 1, p. 11-26.

Masuda, A. and Kushiro, I., 1970. Experimental determination of partition coefficients of ten rare earth elements and barium between clinopyroxene and liquid in the synthetic silicate system at 20 kilobar pressure, Contrib. Mineral. Petrol., v. 26, p. 42-49.

Masuda, A and Matsui, Y., 1966. The difference in lanthanide abundance pattern between the crust and the chondrite and its possible meaning to the genesis of crust and mantle, Geochim. Cosmochim. Acta, v. 30 , p. $239-250$.

Masuda, A. and Shimizu, H., in preparation. Mathematical treatment of solid-type REE patterns: Linear bulk partition model.

Masuda, A., Shimizu, H., and Inenaga, N., 1977. Search for chemical effect on partitioning of rare-earth elements in the crystallization process of basaltic systems at $20 \mathrm{~kb}$, with some applications, Geochem. J., v. 11 p. 21-32.

Philpotts, J.A., Schnetzler, C.C., and Hart, S.R., 1969. Submarine basalts: some $\mathrm{K}, \mathrm{Rb}, \mathrm{Sr}, \mathrm{Ba}$, rare-earth, $\mathrm{H}_{2} \mathrm{O}$ and $\mathrm{CO}_{2}$ data bearing on their alteration, modification by plagioclase, and possible source materials, Earth Planet. Sci. Lett., v. 7, p. 293-299

Puchelt, H. and Emmermann, R., 1977. REE characteristics of ocean floor basalts from the MAR $37^{\circ} \mathrm{N}$ (Leg 37 DSDP), Contrib. Mineral. Petrol., v. 62, p. 43-52. 

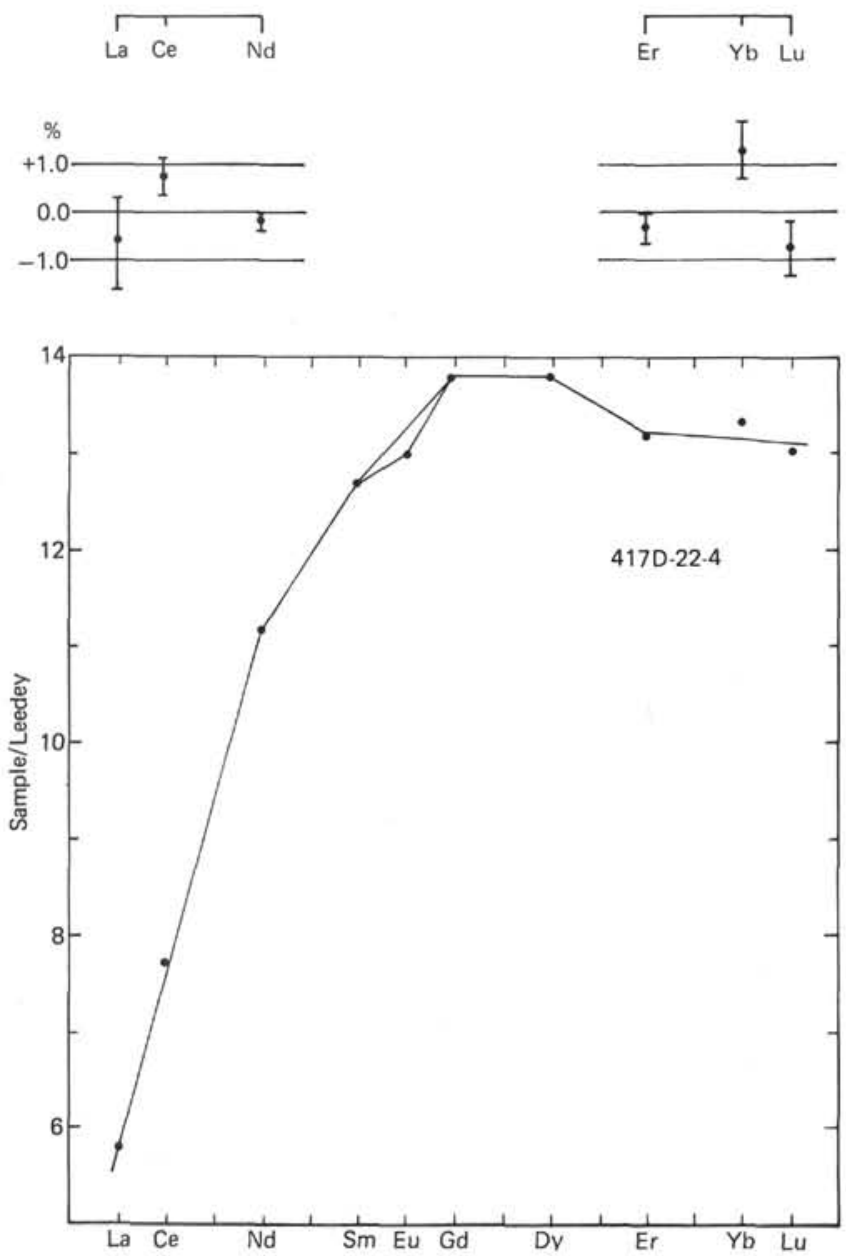

Figure 5a. Enlarged diagram for Section 417D-22-4 (cf. Figure 3), with deviations (\%) from regression lines.

Puchelt, H., Emmermann, R., and Srivastava, R.K., 1977. Rare earth and other trace elements in basalts from the Mid-Atlantic Ridge $36^{\circ}$ N. In Aumento, F., Melson, W.G., et al., Initial Reports of the Deep Sea Drilling Project, v. 37: Washington (U.S. Government Printing Office), p. 581-589.

Schilling, J.G., 1971. Sea-floor evolution: rare earth evidence, Phil. Trans. Ray. Soc. Lond., v. 268, p. 663-706. , 1976. Rare-earth, Sc, Cr, Fe, Co, and $\mathrm{Na}$ abundances in DSDP Leg 38 basement basalts: Some additional evidence
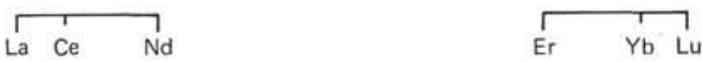

$\%$
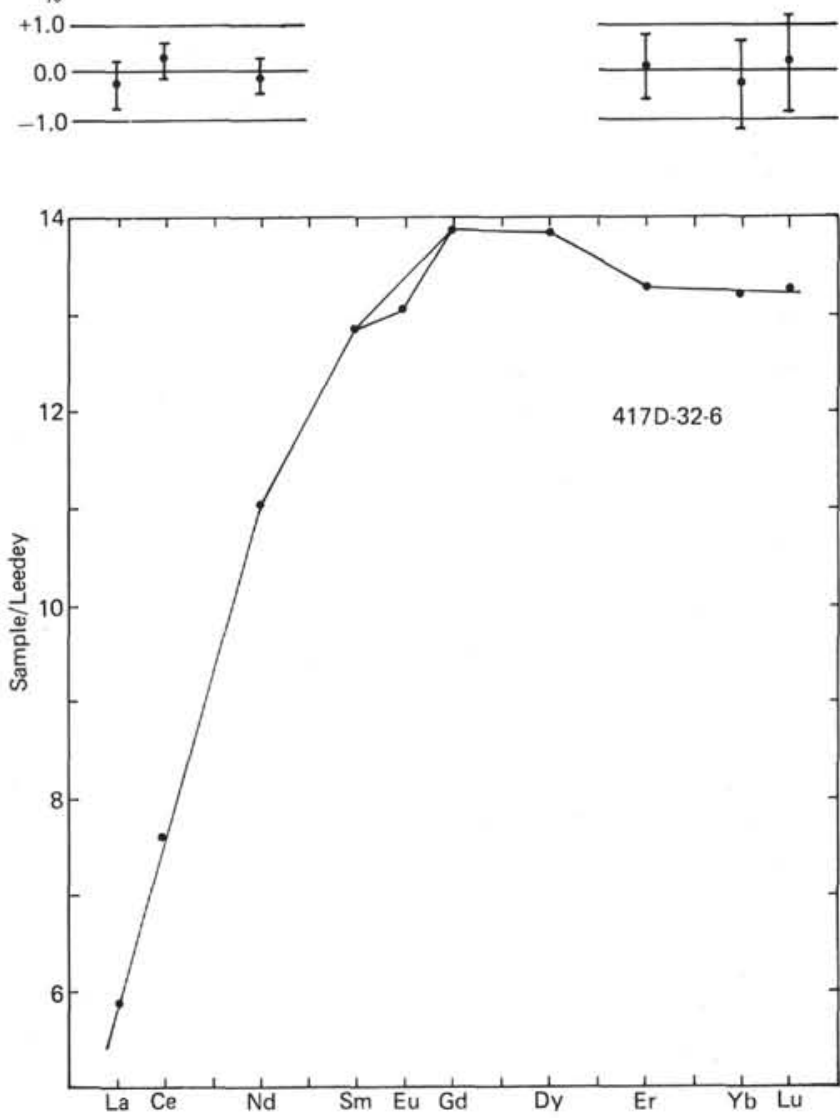

Figure 5b. Enlarged diagram for Section 417D-32-6 (cf. Figure 3), with deviations (\%) from regression lines.

on the evolution of the Thulean Volcanic Province. In Talwani, M., Udintsev, G., et al., Initial Reports of the Deep Sea Drilling Project, v. 38: Washington (U.S. Government Printing Office), p. 741-750.

Schilling, J.G., Kingsley, R., and Bergeron, M., 1977. Rare earth abundances in DSDP Sites 332, 334 and 335, and inferences on the Azores mantle blob activity with time. In Aumento, F., Melson, W.G., et al., Initial Reports of the Deep Sea Drilling Project, v. 37: Washington (U.S. Government Printing Office), p. 591-597. 


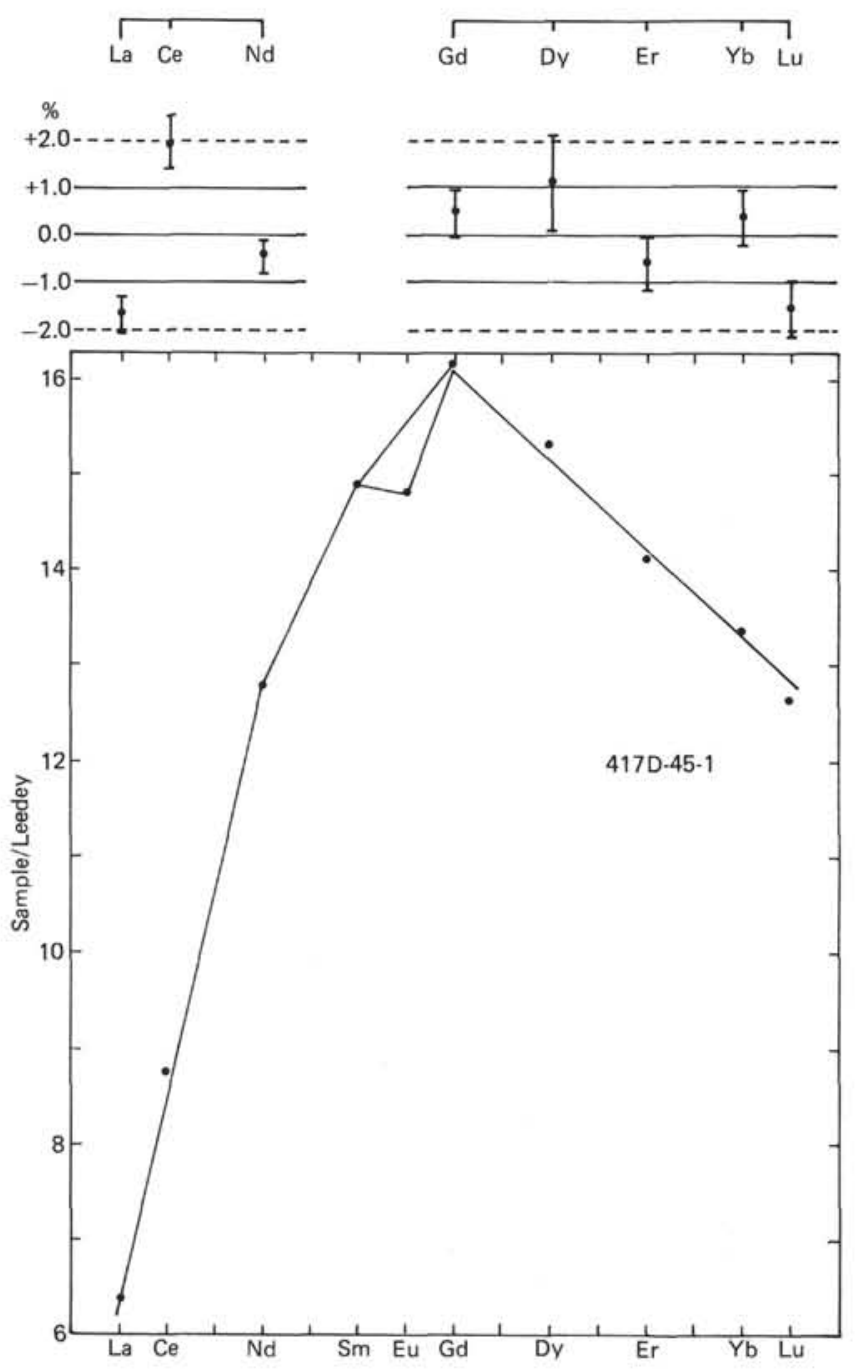

Figure 5c. Enlarged diagram for Section 417D-45-1 (cf. Figure 3), with deviations (\%) from regression lines.
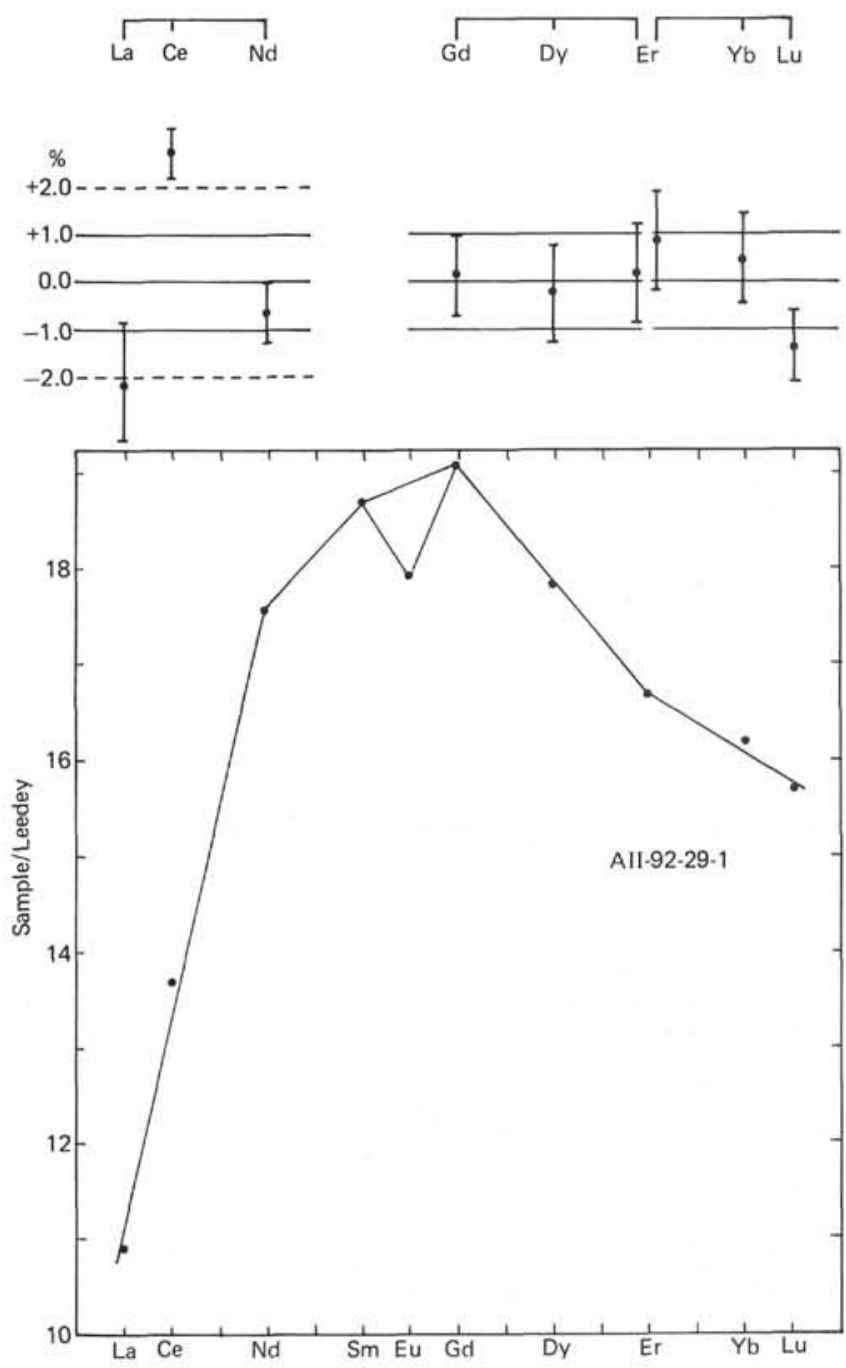

Figure 6. Enlarged diagram for AII 92-29-1 (cf. Figure 3), with deviations (\%) from regression lines. 


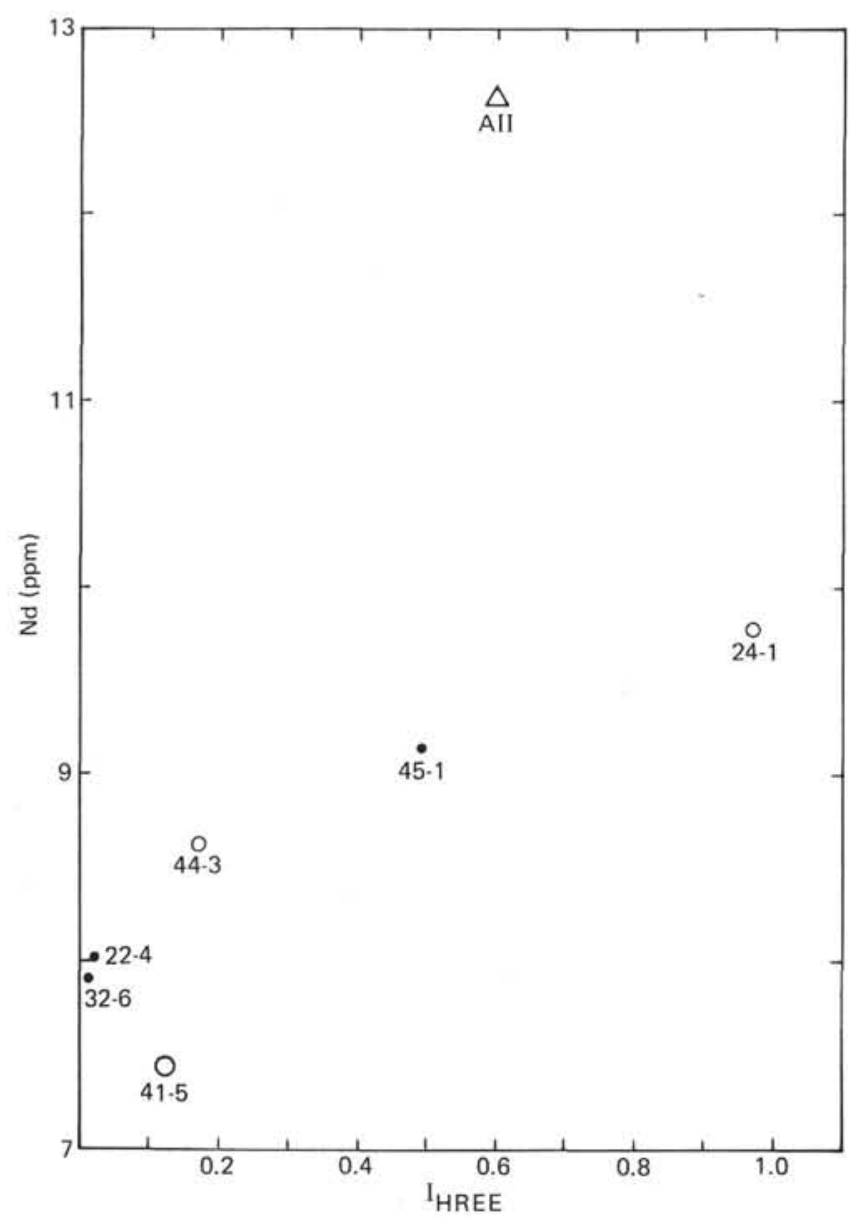

Figure 7. Relationship between $N d$ content and $I_{H R E E}$.

\section{APPENDIX}

Let us consider the concentration, $\mathrm{C}_{\mathrm{s}}^{\mathrm{a}, \mathrm{b}}$, of a certain rare-earth element in solid-type material system wholly representing solid separated between stages, $a$ and $b$, corresponding to residual melt fractions $\mathrm{f}_{\mathrm{w}}^{\mathrm{b}}$ and $\mathrm{f}_{\mathrm{w}}^{\mathrm{b}}$. For the above concentration, we have

$$
C_{s}^{a, b}=\frac{f_{w}^{a} C_{1}^{a}-f_{w}^{b} C_{1}^{b}}{f_{w}^{a}-f_{w}^{b}}
$$

in which $C_{1}^{a}$ and $C_{1}^{b}$ are the concentrations in melts at stages $a$ and $b$, respectively. Normalizing against initial concentration $\mathrm{Co}_{0}$ gives

$$
\mathrm{C}_{\mathrm{s}}^{\mathrm{a}, \mathrm{b}} / \mathrm{C}_{\mathrm{o}}=\frac{\mathrm{f}_{\mathrm{w}}^{\mathrm{a}}\left(\mathrm{C}_{1}^{\mathrm{a}} / \mathrm{C}_{\mathrm{o}}\right)-\mathrm{f}_{\mathrm{w}}^{\mathrm{b}}\left(C_{1}^{\mathrm{b}} / \mathrm{C}_{\mathrm{o}}\right)}{\mathrm{f}_{\mathrm{w}}^{\mathrm{a}}-\mathrm{f}_{\mathrm{w}}^{\mathrm{b}}}
$$

Assumption of solidification process with solid-surface equilibrium leads to

$$
\begin{aligned}
& \mathrm{C}_{1}^{\mathrm{a}} / \mathrm{C}_{\mathrm{o}}=\left(\mathrm{f}_{\mathrm{w}}^{\mathrm{a}}\right)^{\mathrm{k}-1} \\
& \mathrm{C}_{1}^{\mathrm{b}} / \mathrm{C}_{\mathrm{o}}=\left(\mathrm{f}_{\mathrm{w}}^{\mathrm{b}}\right)^{\mathrm{k}-1}
\end{aligned}
$$

where $\mathrm{k}$ is a bulk partition coefficient pertaining to the element concerned. Combining Equations 2, 3a, and $3 \mathrm{~b}$ leads finally to

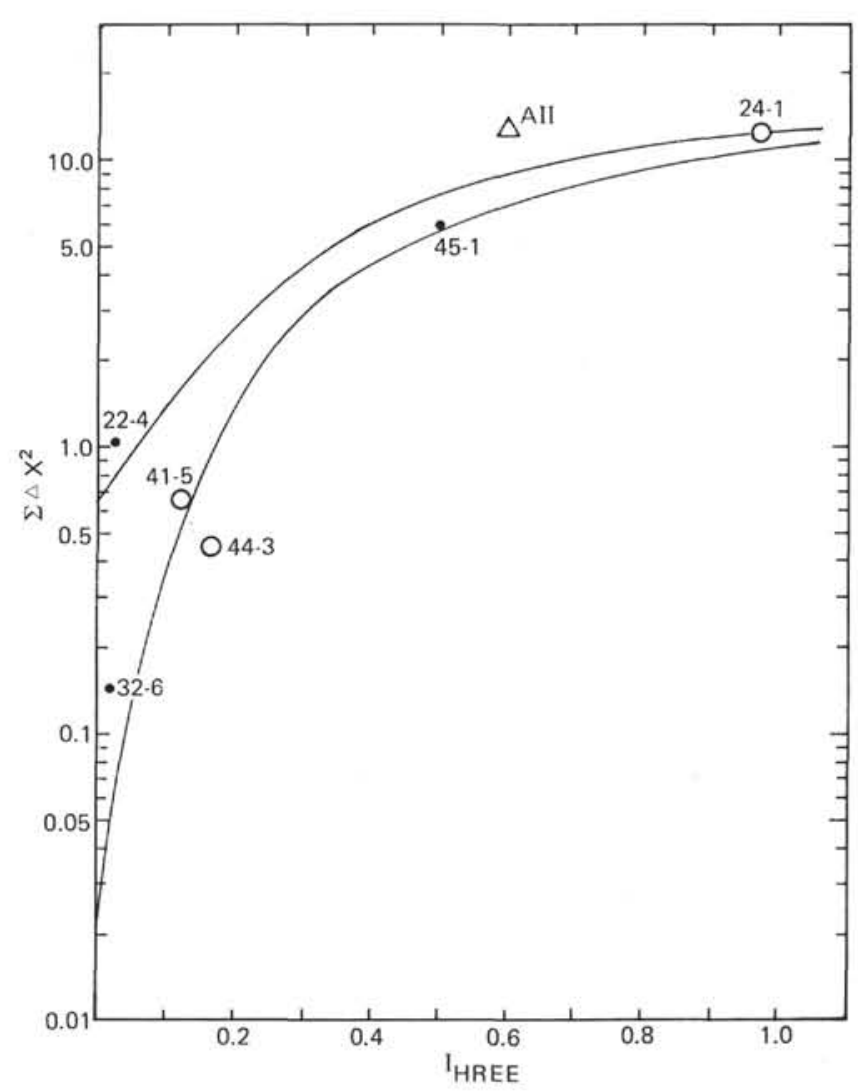

Figure 8. Relationship between $\Sigma(\Delta x)^{2}$ (cf. text) and $I_{H R E E}$ two curves are theoretically drawn, employing different parameters, independently of observations.

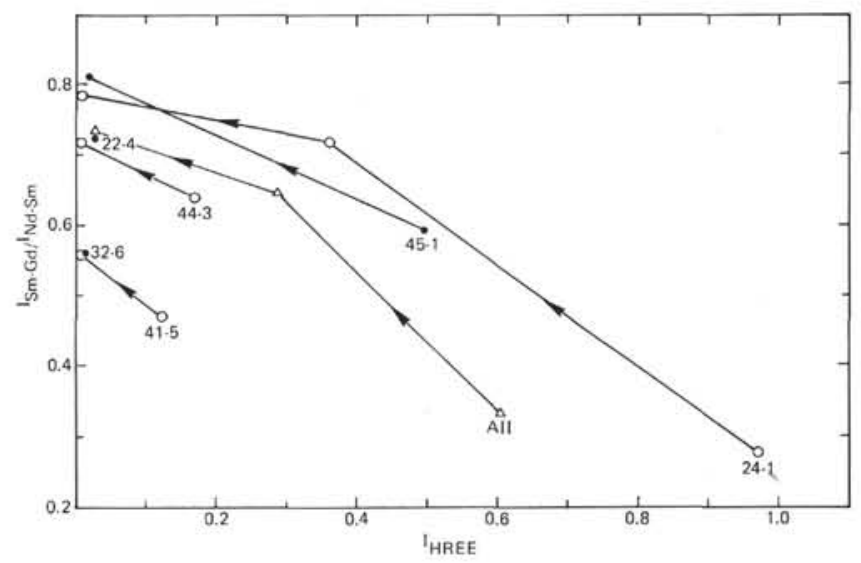

Figure 9. Effect of reinstatement of $I_{H R E E}$ to horizontality on $I_{S m-G d} / I_{N d-S m}$.

$$
\mathrm{C}_{\mathrm{s}}^{\mathrm{a}, \mathrm{b}} / \mathrm{C}_{\mathrm{o}}=\frac{\left(\mathrm{(f}_{\mathrm{w}}^{\mathrm{a}}\right)^{\mathrm{k}}-\left(\mathrm{f}_{\mathrm{w}}^{\mathrm{b}}\right) \mathrm{k}}{\mathrm{f}_{\mathrm{w}}^{\mathrm{a}}-\mathrm{f}_{\mathrm{w}}^{\mathrm{b}}}
$$

This general form is highly expedient in theoretical quantitative treatment of solid-type REE patterns. (To avoid probable confusion, it is additionally noted here the $\mathrm{k}-1$ in Equations $3 \mathrm{a}$ and $3 \mathrm{~b}$ and $\mathrm{k}$ in Equation 4 work as powers.) 